\title{
Determining Rank-Size Distribution of Urban Centres of Eastern Uttar Pradesh, India
}

\author{
Dr. (Mrs.) Kiran Kumari \\ Associate Professor, Department of Geography Rajiv Gandhi University, Rono Hills, Doimukh -791112 \\ Arunachal Pradesh (India)
}

\begin{abstract}
The concept of city-size distribution has riveted the attention of social scientists during the last four decades. The existence of three types of city-size distribution has been noted in the literature on city-size distribution and settlement system. These are central place, rank-size and primate city distributions. This paper is primarily concerned with the last two. The Rank-Size rule is one of the methods of analyzing total settlement network in a region and also a tool for analyzing the settlement system that helps in the description and interpretation of the relationship between rank and population size of urban centres. A city-size distribution, in which the largest, city is several times larger than the second largest is known as the primate city-size distribution. The present study aims to examine the validity of Rank-Size Rule in India's backward region Eastern Uttar Pradesh. A Stochastic model of the actual and expected population of the primate city and its variation from the estimated one provides interesting results that the urban centres in Eastern U.P. do not completely conform to the rank size rule.
\end{abstract}

Keywords: Rank-Size Rule, Zipf's Law, Primacy Index, Primate City

\section{Introduction}

When we look into the various sizes of urban places in an area, it is commonly observed that there are a few large cities, many medium sized and host of small centres. This trend is universal and can be observed at national or regional. In other words, The distribution of urban centres of varying sizes at different distances in a region is said to have certain relationship between the population size and rank on the one hand and between the spacing and the hierarchical orders on the other under ideal theoretical conditions.

The concept of "Rank-Size Rule" was first propounded during the first quarter of the present century. Though the geographical interest in the size distribution of rank-size regularity owes much to Zipf's National Unity and Disunity, yet as Rosing (1966) has remarked, Zipf was by no means the first person to point towards the regularity of city sizes. This empirical existence of a regular relationship between the size of urban centres and their ranks was first presented by Auerback (1913) in a study of German cities. He was of the opinion that the population of the nth city was $1 / n$th the size of the largest city. Later on Lotka (1924) observed that the urban concentration indicated by the cities of United States fell in the same pattern.

It is a remarkable fact that the distribution of city-sizes exhibits a degree of regularity across various countries and periods in history. The rank-size rule was first of all put scientifically forward by Zipf (1941) as a theoretical model to express the relationship between observed and empirical regularity in the size of settlement hierarchy either urban or rural. This observed phenomenon is often referred to as Zipf's Law, after Zipf (1949) who observed that the logarithm of population size when plotted against the logarithm of the rank of the city produced points close to a straight line, with negative slope. Nowadays (e.g. Brakman et al., 1999, Gabaix, 1999), the term Zipf's Law is often used to refer exclusively to the case of a slope of negative one (rank inversely proportional to size) while for more general negative slope the term rank-size distribution is used. The Rank-Size rule is an empirical observation that expresses the relationship between settlement size (Population) and rank (its numerical position in the series erected by ordering all the settlements in the system from large to small. The idea that settlement size and rank have a systematic relationship was popularized by Zipf (1949), expressed it by simple formula as:

$$
\mathrm{P}_{\mathrm{r}}=\mathrm{P}_{1} / \mathrm{r}^{\mathrm{k}}, \mathrm{r}=1,2, \ldots
$$

Where $\mathrm{q}$ is an exponent approximates to unity. This suggest that if the population of the largest city $\left(\mathrm{P}_{1}\right)$ is divided by any city in the same region, the result will approximately be the population of the city $(\operatorname{Pr})$ whose rank number is used as a divisor.

If the population of the largest city is known, the population of all other cities can be derived from the rank of their size. Thus, if the largest city has $100,000,00$ population the tenth city will have one-tenth or 100,000 and the hundredth city will have one-hundredth as many or 10,000. 


\section{Graphical Representation}

If on a double logarithmic graph, the population of cities is plotted on y-axis and their rank on the $\mathrm{x}$ axis, the distribution will tend to be a straight line at an angle of $-45^{0}$ or slope of -1.00 . If the cities of different regions are so plotted, departures from 'normal' distribution are graphically revealed (Harris, 1968). The frequency distribution of urban centres according to their size and hierarchy, plotted on a double logarithmic graph paper gives a curvilinear trend, which is known as the rank-size curve. The placing of all points for actual and estimated population of urban centres above line of actual rank-size distribution show a sign of underdeveloped economy (Fig. 2). In case of developed economy all these points should either run along the line or below in case of over developed. This represents the paucity of service facilities, poor transportation linkages with the area of umland, unbalanced regional development and the availability of meager income and low productivity in most of the urban centres of Eastern Uttar Pradesh.

\section{Primacy Index}

The degree of primacy of the largest can be measured by the ratio of its population to that of the second larger city or to those of some other ranks of cities combined (Browning \& Gibbs 1966). Primacy is the superlative lead of the largest or primate city over the smaller cities and towns. This may be expressed as a ratio:

Primacy Index $(1)=\mathrm{P}_{1} / \mathrm{P}_{2}$

Where $\mathrm{P}_{1}$ and $\mathrm{P}_{2}$ are the populations of the first and second largest settlements respectively or:

Primary Index (2) $=\mathrm{P}_{1} / \mathrm{P}_{3}$

Where $P_{1}$ and $P_{3}$ are the populations of the first and third settlements respectively. It is necessary under the ranksize rule that the primacy index for $\mathrm{P}_{1}$ and $\mathrm{P}_{2}$ settlements be 2; for $\mathrm{P}_{1}$ and $\mathrm{P}_{3}$ it must be 3 and so on.

\section{Studies in Rank-Size Rule}

A number of scholars- foreign as well as Indian, have examined and utilized the Zipf's rule in analyzing the distribution of urban places in their own own universe. Berry and Garrison (1958), Beckmann(1958), Stewart Jr. (1958), Hagget (1965), Smailes (1967),etc., are some of the principal geographers outside India who have analyzed the principle of size and rank of urban places. Among Indian who have given thought about Zipf's analogy are Qazi Ahmad (1965), A. Ramesh (1965), Mumtaz Khan (1980), S.R. Patil (1969), N.B.K. Reddy (1969), B.L. Singh (1985), Suranjit Kumar Saha (1987), R. Ramachandran (1999), R.B. Mandal (2000), L.N. Verma (2008), etc.

\section{Methodology Used}

The Rank-Size distribution among urban centres of Eastern Uttar Pradesh is investigated for different selected Census year i.e., 1901, 1911...2001. For each census year, the rank and the respective population size of each of the urban settlements which are arranged in the descending order of their population size are plotted in a log-graph showing ranks on the $\mathrm{X}$-axis and the population size of the urban centres on $\mathrm{Y}$-axis. The plots are connected by smooth lines and the trends of the urban settlement for each census year.

\section{Objectives of the Present Study}

The urban centres in a region are believed to have certain relationships, which are supposed to be constant under ideal theoretical conditions. Certain rules have been formulated to explain the relationship between the population size and the rank order on the one hand and between the spacing and hierarchical order on the other. In the present paper, an attempt is been made to examine the validity of such theorizations in respect of urban centres of the study region (Eastern Uttar Pradesh). In order to make the study, more analytical and explicit, an attempt has been made to answer the following questions:

i) How far the size distribution of the urban centres of Eastern Uttar Pradesh follows the rank-size rule?

ii) How much does the size of urban centres deviate from the theoretical norm?

iii) What is the position of each urban place in the theoretical curve?

iv) Has the rank-size relationship been stable during the last 100 years (1901-2001) or has undergone significant changes?

v) It has undergone significant changes, what has and been the nature of changes?

vi) How much is the primacy of the primate city?

\section{Study Area}

Eastern Uttar Pradesh, a peripheral region covering 27 districts of Uttar Pradesh namely Allahabad, Azamgarh, Ambedkar Nagar, Bahraich, Ballia, Basti, Balrampur, Chandauli, Deoria, Faizabad, Ghazipur, Gonda, Gorakhpur, Jaunpur, Kaushambi, Kushinagar, Maharajganj, Mau, Mirzapur, Pratapgarh, Siddharth Nagar, Sant Kabir Nagar, Sant Ravi Das Nagar, Shravasti, Sonbhadra, Sultanpur and Varanasi extends from $23^{\circ}$ 
$50^{\prime}$ North to $28^{\circ} 45^{\prime}$ North latitudes and $81^{\circ} 36^{\prime}$ East to $84^{\circ} 50^{\prime}$ East longitudes covering an area of $85,845 \mathrm{~km}^{2}$, which is nearly $29.2 \%$ of geographical area of Uttar Pradesh ${ }^{1}$.

Its northern limit corresponds with the Indo-Nepal International boundary whereas Bihar-Jharkhand in eastern and Madhya Pradesh-Jharkhand in southern limits of the region. The western boundary of this region is demarcated by the western limits of Bahraich, Gonda, Faizabad, Sultanpur, Pratapgarh and Allahabad districts, as depicted in Fig 1. It comprises of 117 Tahsils, 356 Blocks, 50632 Villages and 202 urban/urban agglomerations.

\section{Decadal Rank-Size Distribution of Urban Centers}

In order to examine the rank-size distribution of urban centres of the study area, 8 double logarithmic graphs showing population size on the ordinate and rank on the abscissa, were drawn for all the centres defined as urban at each census from 1901-2001 (Fig. 2, Fig. 3 \& Fig.4 and Table 1). As is evident from these graphs, the size distribution of urban centres of the study area does not conform to the rank-size rule. An analysis of the deviations from the theoretical rank-size relationship can be made with reference to the exponential lines (E-1 and E-2) which represents the theoretical size distribution of urban centres of the study area calculated on the basis of observed and expected population of the primate city respectively. The expected population of the primate city has been derived by dividing the total population of all the urban centres with the sum of the reciprocals of their ranks.

The curves for the census year 1901 and 1911 do not suggest any conformity with the rank-size rule as depicted in fig.2. All the urban centres are larger in size which is obvious from the fact that all of them lie above the exponential line-1 (E-1). The variation from exponential line-2 (E-2) is also significant. Varanasi the primate city of the study area, had a population of 215223 and 205420 in 1901 and 1911 respectively while according to the rank-size rule its population should have been 244976 and 208574 respectively. Thus, the actual population fell short of 29753 and 3159 to its expected population; the deficiency was -12.15 and -1.15 per cent respectively. While the second largest town Allahabad lies above the exponential line-2. Class $\mathrm{V}^{\text {th }}$ size towns are much bigger than their expected size. The exponential line E-2 located in all the previous graphs has come very close to the exponential line E-1, thus rank size distribution in 1921 shows that the variation between the actual and estimated population of the primate city is very small. Varanasi the primate city had a deficiency of -5.70 and -17.28 per cent to its expected size in 1921 and 1931 respectively. Allahabad, Faizabad and Mirzapur-cumVindhyachal are much larger than their expected size and smaller towns are much smaller than their expected size.

The exponential line E-1 and E-2 has gone little bit far away from each other signifying larger variation in actual and estimated. Varanasi the primate city of the study area, had a population of 203372 and 262838 in 1931 and 1941 respectively while according to the rank-size rule its population should have been 245859 and 297265 respectively. Thus, the actual population fell short of 42487 and 34427 to its expected population; the deficiency was -17.28 and -11.58 per cent respectively. While the second largest town Allahabad lies above the exponential line-2. Class $\mathrm{V}^{\text {th }}$ and $\mathrm{VI}^{\text {th }}$ size towns are much bigger than their estimated size. The primate city, Varanasi had a population of 262838 and 351234 in 1941 and 1951 respectively while according to the rank-size rule its population should have been 297265 and 361219 respectively. Thus, the actual population fell short of 34427 and 9985 to its expected population; the deficiency was -11.58 and -2.76 per cent respectively and again the second largest town Allahabad lies above the exponential line-2. Class $\mathrm{VI}^{\text {th }}$ size towns are much smaller than their expected size in census 1941.

In fig. 3 the graphs of census 1951, shows that a few large towns lies either on or near the line E-1. While the second largest town Allahabad lies above the exponential line-2. Varanasi the primate city, had a population of 351234 in 1951, while according to the rank-size rule its population should have been 361219 . Thus, the actual population fell short of 9985 to its expected population; the deficiency was -2.76 per cent respectively. Excluding only few towns are all most all the towns are much smaller than their estimated size. The rank-size distribution in 1961 is transitional in character. The exponential line E-2, hitherto located to the right of line of line E-1 in all the previous graphs has not only come very close to it but has moved to the left of it. Thus, it is apparent that the variation between the actual and expected population of the primate city is very small. The population of the primate city Varanasi was 485083 in 1961 and which according to the rank-size rule its population should have been 459553 . Thus, the observed population exceeded the expected population by 25530 persons or 5.56 per cent. The exponential line-E-2 located for the first time, to the left of line E-1 clearly indicates that the observed population size of urban centres of the study area is larger than their expected size. It is significant to mention that the rank-size distribution in 1961 is relatively closer to the exponential lines as compared to previous graphs. Towns above 50000 to below 5000 are smaller than their expected size. The graphs showing the rank-size distribution for 1971 indicates that the curve depicting the size distribution is gradually shifting from the right to the left of line E-1. The population of the primate city Varanasi was 588608 in 1961 and which according to the rank-size rule its population should have been 557761. Thus, the actual 
population exceeded the estimated population by 30847 persons or 5.53 per cent. Urban centres of above 100000 to below 5000 population are much smaller than their expected size. Azamgarh, Deoria and Balrampur having a population varying between 50000and 30000 persons are lying between the actual and the theoretical lines.

The rank-size distribution in 1981 is again in transitional in character as depicted in fig. 4. The exponential line E-2, located to the right of line of line E-1 in the previous graphs has moved to the right of it. Thus, $t$ the variation between the actual and expected population of the primate city is very large. The population of the primate city Varanasi was 716641 in 1981 and which according to the rank-size rule its population should have been 7700051 . Thus, it had a deficiency of 53410 or -6.94 per cent to its expected size. The exponential line-E-2 located to the right of line E-1 clearly indicates that the observed population size of urban centres of the study area is smaller than their expected size. Towns above 300000 to 600000 and between 13000 and 5000 are larger than their expected size and urban centres varying between 120000 to 60000,30000 to 13000 and below 5000 persons are smaller than their expected size.

In 1991, curve depicting the rank-size distribution is gradually shifting from the right to left to the right. Urban centres between 500000-800000, 59000-77000 and 6300-17000 are larger than their expected size. Towns varying between 17000-45000 and below 6000 persons are smaller than their expected size. Varanasi the primate city of the study area, is much smaller than the expected size having a actual population of 932399 , while according to the rank-size rule its population should have been 1048116. Thus, the actual population fell short of 115717 to its expected population; the deficiency was -11.04 per cent respectively. The graphs of census 2001, shows that a few large towns lies between E-1 and E-2 or near the line E-1. While the second and third largest town Allahabad and Gorakhpur respectively lies above the exponential line E-2. Urban centres between 600000-1000000, 70000-100000 and 7000-22000 are larger than their expected size. Towns varying between 100000-220000, 22000-60000 and below 7000 persons are smaller than their estimated size. Varanasi the primate city had a population of 1103952 in 1951, while according to the rank-size rule its population should have been 1321571. Thus, the actual population fell short of 217619 to its estimated population; the deficiency was -16.47 per cent against the -11.04 per cent recorded in 1991. It speaks of a very slow growth of Vararnasi, the primate city, on the contrary the second and third largest towns Allahabad and Gorakhpur respectively are gaining rapid growth.

A Stochastic model of the actual and estimated population of the primate city and its variation from the estimated one provides interesting results as given in Table 1. Thus, it is evident from the above discussion that the urban centres in Eastern Uttar Pradesh do not completely conform to the rank-size rule.

\section{Primate City}

Varanasi is the primate city of Eastern Uttar Pradesh since the beginning of the present century. Its actual population is 1103952 while its expected population according to the rank size rule is 1321571 in 2001, thus recording16.47 percentage less. It signifies that the actual population of all the urban centres of the study region is less than the expected population. Allahabad the second primate city, according to the 'rank-size rule' its ratio must be $1: 2$ but its actual ratio is 1:1.25, likewise actual ratio of every urban centres is less than the expected ratio.

\section{Rank Fluctuations of Urban Centres}

"No Phenomenon illustrates the significance of changing geographical values more profoundly than the relative status of town" (Smailes, 1967, p.62). The rank of the urban centres is decided by the population size of that centre vis-à-vis other centres. The change in the rank may be positive or negative as it is purely relative; a change in rank occurs only in relation to other urban centres of the region. However, the degree of freedom to change rank within the urban hierarchy vary from one rank to the other. For example, the largest urban centres cannot increase its rank; it can either maintain its first position or come down to a lower rank. Conversely, the smallest urban centres can only retain its rank or increase it; it cannot move further down in rank.

Table 2, shows the rank of 202 urban centre of the study area and changes in their rank over a period of ten decades (1901-2001). Table reveals that Varanasi, the largest city in 1901and Allahabad the second primate city maintained their rank throughout the whole period. Gorakhpur starting in the fifth rank in 1901 had risen to third position from 1911 onwards. There was a great fluctuations found in Maunath Bhanjan, where in 1901 it was on $12^{\text {th }}$ rank in, 1911, it came to $10^{\text {th }}$ rank again it fell to $11^{\text {th }}$ rank in 1921 , and again it was on $10^{\text {th }}$ position and after that, it rises to $8^{\text {th }}$ position from 1951 to 1981 and again it rises to score $5^{\text {th }}$ in 1941 and $4^{\text {th }}$ position in 2001 Census. Mirzapur maintained its $4^{\text {th }}$ rank in 1901 but fell to $5^{\text {th }}$ in 1911 and again retained its fourth position from 1931 to 1991 but, fell down to $5^{\text {th }}$ position in 2001. Bahraich gained its $7^{\text {th }}$ position in 1911 to 1991 and again rises to $6^{\text {th }}$ position in 2001 Census. Jaunpur ranked $6^{\text {th }}$ position from 1901 to 1971 and rises to $5^{\text {th }}$ and again in 1991 fell to $6^{\text {th }}$ and $7^{\text {th }}$ rank in 1991 and 2001 respectively. Faizabad witnessed a fall from $3^{\text {rd }}$ in 
1901 to $8^{\text {th }}$ place in 2001. Gonda moved from $11^{\text {th }}$ to $9^{\text {th }}$ position in 1901 and 2001 respectively. Basti witnessing many fluctuations maintained at $10^{\text {th }}$ position from 1951 onwards.

Ghazipur, Azamgarh, Tanda, Balrampur, Mubarakpur, Ayodhya, Nanpara, Ramnagar, Rudauli, Gaura Barhaj, Chunar, Muhammadabad Gohna, Rasra, Rudrapur, Lar, Mehdawal, Shahganj, Colonelganj, Allahabah city, Ahraura, Machhlishahar, Reoti, Sikanderpur, Saidpur, Tulsipur, Phulpur, Bhinga, Chitbara Gaon, Mariahu, Bansdih, Sewarhi, Barhalganj, Sahatwar, Siswa Bazar, Maniyar, Maruadih Raiway Settlement, Mau Aima, Gopiganj, Mongra Badshahpur, Varanasi, Majhauli Raj, Belthara Road, Jhusi Kohna, Bahadurganj, Nawabganj, Maghar, Sarai Aquil, Sarai Mir, Bharatganj, Pipraich, Kachhwa, Pachperwa, Bhatni Bazar, Manjhanpur, Bansgaon, Faizabad city, Chakia, Jhusi, Manikpur, Ramkola, Pipri, Ikauna, Amethi, Koraon, Gosaiganj, Bhatpar Rani, Kerakat, Pratapgarh city, Chopan, Bikapur, Nizamabad, Gyanpur, Adari, Phulwaria, Kurthi Jafarpur, Katghar lalganj, Dostpur, Barhani Bazar, Dudhi, Kaptainganj, Sirsa, Pipiganj, Bhadarsa, Illtifatganj, Atraulia, Hata, Ledwa Mahua, Didarnagar Fatehpur Bazar, Risia Bazar, Ajmatgarh, Gola Bazar, Sadat, Jiyanpur, Dohrighat, Rampur Karkhana, Hariharpur, Khargupur, Mankapur, Patti, Jafarabad, Churk Ghurma, Shohratgarh, Phulpur, Katra Medniganj, Kandwa, Maharajganj, Ghorawal, Katra, Gangapur and Amila witnessed a tremendous fall in their ranks. On the contrary, Deoria, Ballia, Sultanpur, Bela Pratapgarh, Padrauna, Akbarpur, Robertsganj Mohammadabad and Utraulia are those urban centres that moved considerably in the urban hierarchy during 100 years of the present century.

The fluctuations in the rank of urban centres may be attributed to several factors responsible for urban growth such as industrialization, developments of transport and accessibility, administration, etc.

Thus, the study of spatial distribution pattern of urban centres of the study area reveals the following conclusions:

i) The urban centres in Eastern Uttar Pradesh do not completely conform to the rank size rule. The actual population of all the urban centres of the study region is less than the expected population.

ii) The actual population and expected population of Varanasi city is 1103952 and 1321571 respectively in 2001, thus recording 16.47 percentage less.

iii) Varanasi, the primate city and Allahabad maintained its rank through out the whole period. The rank of 202 urban centre shows continuous changes in their rank over a period of ten decades (1901-2001) only due to urbanization

\section{References}

[1]. Auerback, F. (1913): Das Gesetz Der Bevolkerungskonzentation, Petermnn's Geographischa Mittilungen, Vol. 59, No. 1, pp. 74-6 as quoted in Robson 1973.

[2]. Berry, B.J.L. and Garrison, W.L.(1958): “Alternative Explanations of Urban Rank-Size Relationship,” Annals of the Association of American Geographers, Vol. 48, p.83.

[3]. Berry, B.J.L. (1961): “City-Size Distribution and Economic Development”, Economic Development and Cultural Change, Vol. 9, p. 573-588.

[4]. Brakman, Stephen, Harry Garretsen, Charles Van Marrewijik and Mariane Van Den Berg. (1999): "The Return of Zipf: Towards a Further Understanding of the Rank-Size Distribution”, Journal of Regional Science, Vol. 39, p.183-213.

[5]. Duncan, O.D. (1957): “The Measurement of Population Distribution" Population Studies, July 1957, p.43.

[6]. Gabaix, Xavier (1999): “Zipf's Law for Cities: An Explanation”, The Quarterly Journal of Economics, Vol.114, p.739-767.

[7]. Gibbs, J.P.(1961): “Urban Research Methods”, D. VanNostrand Co. Inc., New York, 1961, p. 441.

[8]. Hagget, P. (1965): Locational Analysis in Human Geography, Arnold, London, pp.,100-13.

[9]. Harris, C.D. (1968): City and Region in the Soviet Union, Beckinsale, R.P., and Houston, J.H. (Ed.), Urbanization and its Problems, Oxford, pp. 277-96.

[10]. Israd, W. (1956): Location and Space Economy, John Wiley, New York, pp.55-60.

[11]. Kumari, Kiran (2008): “Urbanization and Regional Development in Eastern Uttar Pradesh" Unpublished Ph.D. Thesis, Chapter 4, p. 106-154.

[12]. Lotka, A.J. (1924): Elements of Physical Biology (Baltimore) (New Edition, New York, 1965, entitled Elements of Mathematical Biology).

[13]. Mandal, R.B. (2000): “Urban Geography, Concept Publishing Company, New Delhi, p.221-233.

[14]. Patil, S.R. (1969): A Comparative Study of Rank-Size Relationship of the Urban Settlements of Mysore States, Indian Geographical Journal, Vol. XLIV, No. 182, pp.35-43.

[15]. Ramesh, A. (1965): "Rank-Size Relationship and Spatial Distribution of Urban Centres, Chapter IV, The Tamil Nad Deccan-A Study in Urban Settlements, Unpublished Ph.D. Thesis, Banaras Hindu University, pp.74-93.

[16]. Reddy, N.B.K. (1969): A Comparative Study of Urban Rank-Size Relationship in the Krishna and Godavari Deltas and South Indian States, The National Geographical Journal of India, Varanasi, Vol. XV, II, pp.63-89.

[17]. Rosing, K.E. (1966): “A Rejection of the Zipf Model (Rank-Size Rule) in Relation to City Size,” The Professional Geographer, Vol. 18, 1966, pp.75-82.

[18]. Saha, Suranjit Kumar (1987): “A Rank-Size Distribution of Cities and Urban Policy: The Case of Bihar, India, TWPR, 9 (4).

[19]. Singer, H.W. (1936): "Courbes des populations: A Parallel to Pareto's Law, Economic Journal, Vol.46, pp.254-63, as quoted in Robson (1973).

[20]. Simon, H.A. (1955): On a Class of Skew Distribution Functions, Biometrics, Vol. 42, pp. 425-40, Reprinted in Models of Man, Wiley, New York (1957). 
[21]. Smaile, A.E. (1966): The Geography of Towns, Hucthinson, London, p.62.

[22]. Stewart, C.T.Jr. (1958): "The Size and Spacing of Cities", Geographical Review, 48, 1958, pp. $222-245$.

[23]. Verma, L.N. (2008): "Urban Geography”, Rawat Publications, Jaipur, India, pp.183-190.

[24]. Zipf, George K. (1941): National Unity and Disunity, Bloomnibhon, Illinios, Principia Press.

[25]. Zipf, George K. (1949): Human Behaviour and the Principle of Least Effort, Cambridge: M.A: Addison-Wesley Publishing Company.

FIG. 1

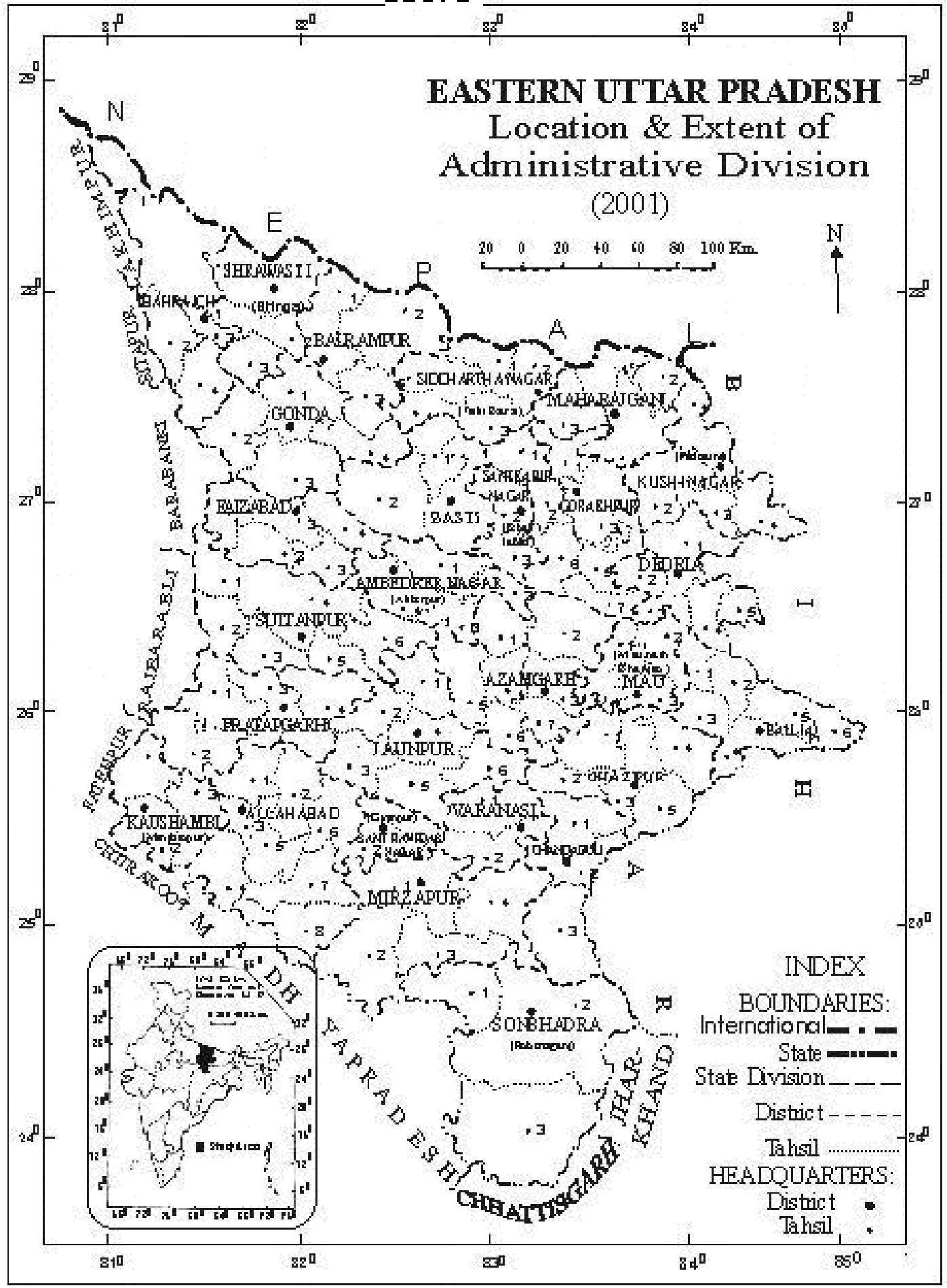



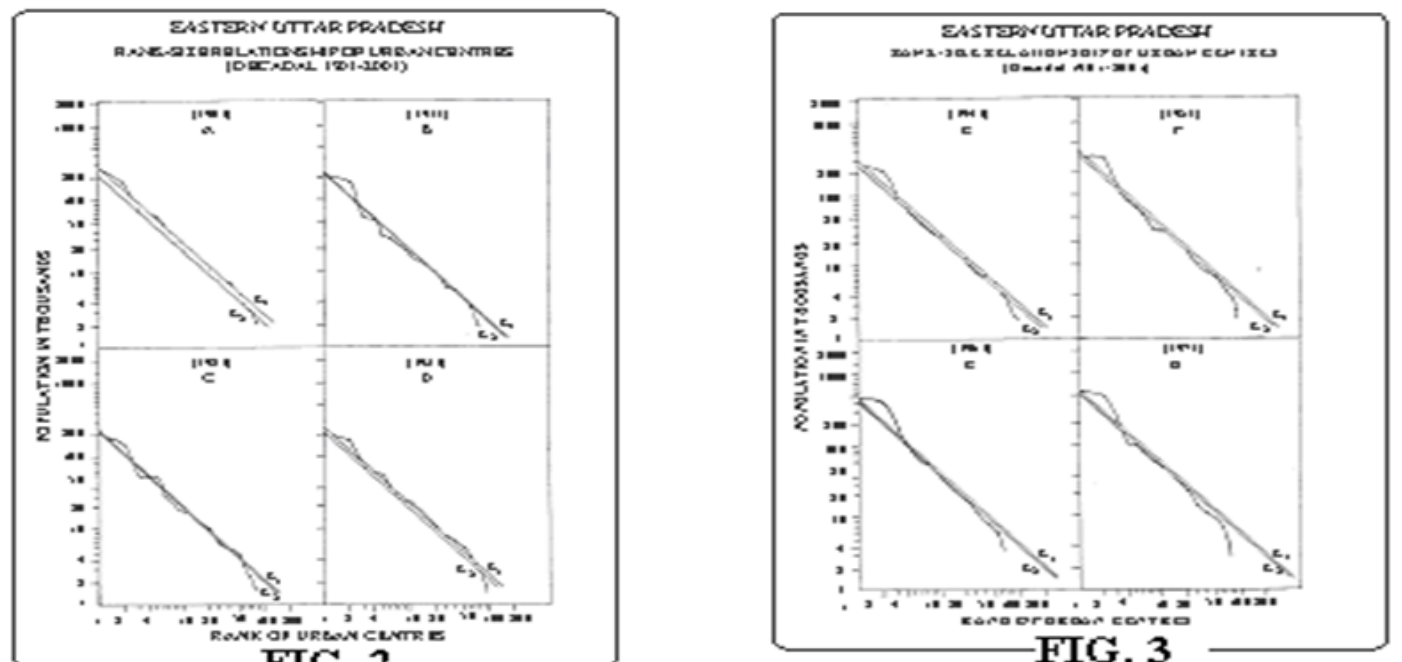

FIG. 2

FIG. 3

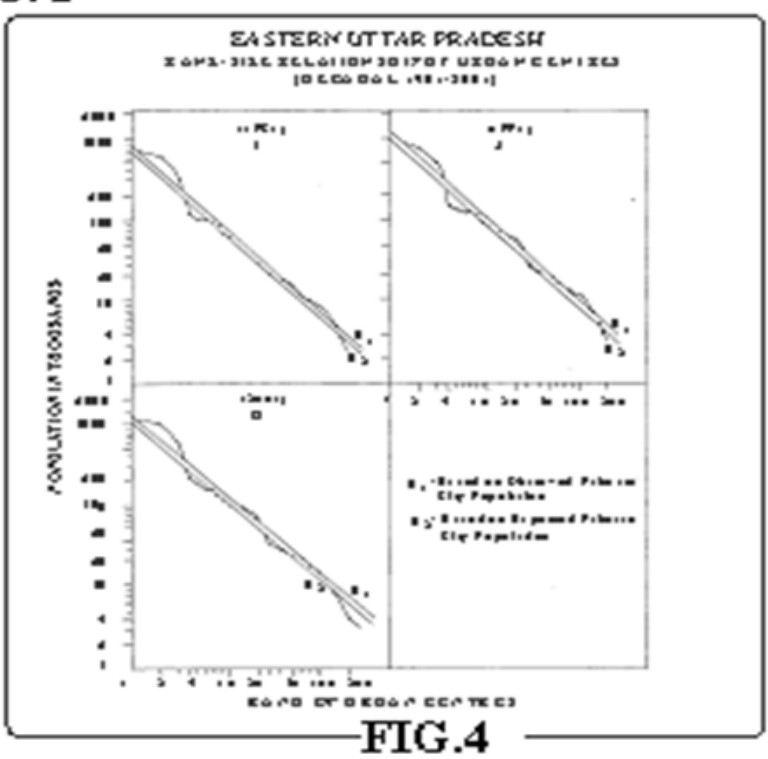

Table 1: Stochastic model of the population of primate city in Eastern Uttar Pradesh (1901-2001)

\begin{tabular}{|c|c|c|c|c|c|c|c|}
\hline $\begin{array}{c}\text { Census } \\
\text { Year }\end{array}$ & $\begin{array}{c}\text { Number } \\
\text { of } \\
\text { Towns }\end{array}$ & $\begin{array}{c}\text { Sum of } \\
\text { Reciprocal } \\
\text { or Ranks }\end{array}$ & $\begin{array}{c}\text { Sum of } \\
\text { Urban } \\
\text { Population }\end{array}$ & $\begin{array}{c}\text { Actual } \\
\text { Population of } \\
\text { Primate City }\end{array}$ & $\begin{array}{c}\text { Estimated } \\
\text { Population }\end{array}$ & $\begin{array}{c}\text { Difference } \\
\text { of Actual \& } \\
\text { Estimated } \\
\text { Population }\end{array}$ & $\begin{array}{c}\text { Difference } \\
\text { as \% of the }\end{array}$ \\
\hline 1901 & 82 & 5.0218 & 1230221 & 215223 & 244976 & -29753 & -12.15 \\
\hline 1911 & 79 & 4.9847 & 1039703 & 205420 & 208579 & -3159 & -1.51 \\
\hline 1921 & 89 & 5.1032 & 1082496 & 200022 & 212121 & -12099 & -5.70 \\
\hline 1931 & 94 & 5.1576 & 1268040 & 203372 & 245859 & -42487 & -17.28 \\
\hline 1941 & 94 & 5.1576 & 1533173 & 262838 & 297265 & -34427 & -11.58 \\
\hline 1951 & 97 & 5.1888 & 1874294 & 351234 & 361219 & -9985 & -2.76 \\
\hline 1961 & 56 & 4.6254 & 2125616 & 485083 & 459553 & 25530 & 5.56 \\
\hline 1971 & 75 & 4.9331 & 2751489 & 588608 & 557761 & 30847 & 5.53 \\
\hline 1981 & 166 & 5.724 & 4407774 & 716641 & 770051 & -53410 & -6.94 \\
\hline 1991 & 180 & 5.8047 & 5412297 & 1048118 & 932399 & 115717 & -12.41 \\
\hline 2001 & 202 & 5.9197 & 7823303 & 1103952 & 1321571 & -217619 & -16.47 \\
\hline
\end{tabular}

Source : Census of India, 2001, Uttar Pradesh, Volume-I, Primary Census 
Table-2: Rank fluctuations of urban centres in Eastern U.P. (1901-2001)

Table-2

Rank fluctuations of urban centres in Eastern U.P. (1901-2001)

\begin{tabular}{|c|c|c|c|c|c|c|c|c|c|c|c|c|}
\hline RANK & URBAN CENTRES & 1901 & 1911 & 1921 & 1931 & 1941 & 1951 & 1961 & 1971 & 1981 & 1991 & 2001 \\
\hline 1 & Varanasi (M.Corp+OG.) & 1 & 1 & 1 & 1 & 1 & 1 & 1 & 1 & 1 & 1 & 1 \\
\hline 3 & Gorakhpur (M.Corp.) & 5 & 3 & 3 & 3 & 3 & 3 & 3 & 3 & 3 & 3 & 3 \\
\hline 4 & Maunath Bhanjan (MB) & 12 & 10 & 11 & 11 & 10 & 8 & 8 & 8 & 8 & 5 & 4 \\
\hline 5 & Mirzapur (Vindhyachal) & 4 & 5 & 5 & 4 & 4 & 4 & 4 & 4 & 4 & 4 & 5 \\
\hline 8 & Faizabad (MB) & 3 & 4 & 4 & 5 & 5 & 5 & 5 & 5 & 6 & 8 & 8 \\
\hline 9 & Gonda (MB) & 11 & 12 & 13 & 9 & 11 & 11 & 9 & 9 & 9 & 9 & 9 \\
\hline 10 & Basti (MB) & 16 & 17 & 12 & 10 & 14 & 10 & 10 & 10 & 10 & 10 & 10 \\
\hline 11 & Deoria (MB) & 79 & 63 & 43 & 41 & 16 & 16 & 16 & 15 & 14 & 12 & 11 \\
\hline 12 & Ghazipur(M.B.+O.G.) & 7 & 8 & 8 & 8 & 9 & 9 & 12 & 12 & 13 & 14 & 12 \\
\hline 17 & Tanda (MB) & 9 & 9 & 10 & 12 & 12 & 13 & 13 & 13 & 15 & 16 & 17 \\
\hline 18 & Bhadohi (MB) & - & - & 82 & 24 & 90 & 19 & 19 & 19 & 20 & 19 & 18 \\
\hline 19 & Balrampur (MB) & 13 & 13 & 14 & 13 & 8 & 15 & 15 & 16 & 19 & 20 & 19 \\
\hline 20 & Bela pratapgarh (MB) & 34 & 37 & 25 & 25 & 23 & 21 & 18 & 18 & 16 & 18 & 20 \\
\hline 21 & Mubarakpur & 14 & 14 & 16 & 17 & 24 & 22 & 21 & 20 & 24 & 22 & 21 \\
\hline 22 & Renukoot & - & - & - & - & - & - & 28 & 27 & 21 & 21 & 22 \\
\hline 23 & Obra & - & - & - & - & - & - & - & 40 & 29 & 23 & 23 \\
\hline 24 & Ayodhya & - & - & - & - & - & - & - & - & 22 & 24 & 24 \\
\hline 25 & Padrauna (MB) & 43 & 47 & 26 & 28 & 28 & 27 & 26 & 22 & 26 & 26 & 25 \\
\hline 26 & Nanpara (MB) & 21 & 20 & 22 & 20 & 21 & 25 & 25 & 24 & 25 & 27 & 26 \\
\hline 27 & Ramnagar (MB) & 19 & 16 & 18 & 18 & 22 & 23 & 22 & 26 & 27 & 29 & 27 \\
\hline 28 & Khalilabad (MB) & - & - & - & - & - & - & - & 33 & 35 & 32 & 28 \\
\hline 36 & Robertsganj (MB) & - & - & - & 83 & 82 & 82 & 47 & 61 & 46 & 47 & 36 \\
\hline 37 & Mohammadabad & 38 & 35 & 37 & 44 & 40 & 34 & & 34 & 40 & 40 & 37 \\
\hline 38 & Muhamadabad Gohna & 31 & 32 & 28 & 35 & 57 & 60 & 46 & 53 & 75 & 71 & 38 \\
\hline 39 & Jalalpur & 39 & 52 & 55 & 64 & 87 & 35 & 30 & 29 & 36 & 36 & 39 \\
\hline 40 & Zamania & 50 & 60 & 54 & 53 & 49 & 40 & - & - & 45 & 44 & 40 \\
\hline 41 & Nautanwa (MB) & - & - & - & 66 & 52 & 46 & - & - & 44 & 45 & 41 \\
\hline 42 & Rasra (MB) & 26 & 22 & 27 & 31 & 27 & 28 & 27 & 31 & 37 & 41 & 42 \\
\hline 43 & Mugalsarai Rly. Settl. & - & - & - & - & - & 43 & 33 & 28 & 32 & 37 & 43 \\
\hline 44 & Chandauli (N.P.) & - & - & - & - & - & - & - & 70 & 95 & 104 & 44 \\
\hline 45 & Utraula (MB) & 46 & 34 & 35 & 40 & 38 & 37 & 35 & 35 & 42 & 38 & 45 \\
\hline 46 & Rudrapur & 30 & 26 & 24 & 32 & 34 & 38 & - & - & 43 & 43 & 46 \\
\hline 47 & Maharajganj (MB) & - & - & - & - & - & - & - & - & - & 58 & 47 \\
\hline 48 & Lar & 37 & 30 & 50 & 51 & 48 & 87 & - & & - & 177 & 48 \\
\hline 49 & Shahjanwa & - & - & - & - & - & - & - & - & - & - & 49 \\
\hline 50 & Mehdawal & 22 & 25 & 23 & 21 & 26 & 26 & - & - & 39 & 42 & 50 \\
\hline 51 & Shahganj (MB) & 47 & 54 & 48 & 49 & 47 & 52 & 40 & 41 & 48 & 48 & 51 \\
\hline 52 & Colonelganj (MB) & 44 & 45 & 39 & 45 & 42 & 39 & 36 & 38 & 49 & 46 & 52 \\
\hline 53 & Allahabad (CB) & - & - & - & 23 & 18 & 17 & 20 & 21 & 23 & 25 & 53 \\
\hline 54 & Khamaria & - & - & - & - & - & - & - & - & 73 & 55 & 54 \\
\hline 55 & Ahraura & 18 & 49 & 20 & 26 & 25 & 30 & 34 & 42 & 53 & 51 & 55 \\
\hline 56 & Lal Gopalganj Nindaura & - & - & - & - & - & - & - & - & 59 & 49 & 56 \\
\hline 57 & Machhlishahr & 32 & 40 & 34 & 42 & 33 & 51 & 41 & 50 & 65 & 56 & 57 \\
\hline 58 & Anpara & - & - & - & - & - & - & - & - & - & - & 58 \\
\hline
\end{tabular}




\begin{tabular}{|c|c|c|c|c|c|c|c|c|c|c|c|c|}
\hline 69 & Chitbara Gaon & 28 & 51 & 70 & 27 & 36 & 32 & - & - & 50 & 65 & 69 \\
\hline 70 & Mariahu & 61 & 68 & 68 & 73 & 70 & 70 & 50 & 55 & 77 & 72 & 70 \\
\hline 71 & Bansdih & 24 & 27 & 32 & 29 & 29 & 31 & - & - & 54 & 60 & 71 \\
\hline 72 & Sewarhi & - & - & - & - & - & - & - & 56 & 66 & 61 & 72 \\
\hline 73 & Lohata & - & - & - & - & - & - & - & 68 & 94 & 90 & 73 \\
\hline 74 & Barhalganj & 51 & 56 & 52 & 58 & 75 & 55 & 44 & 49 & 63 & 70 & 74 \\
\hline 75 & Sahatwar & 20 & 44 & 33 & 34 & 32 & 29 & - & - & 56 & 63 & 75 \\
\hline 76 & Siswa Bazar (N.P.) & 72 & 46 & 44 & 47 & 41 & 48 & - & - & 57 & 69 & 76 \\
\hline 77 & Amethi & - & - & - & - & - & - & - & & 114 & 107 & 77 \\
\hline 78 & Maniyar & 29 & 29 & 30 & 37 & 39 & 33 & - & - & 61 & 76 & 78 \\
\hline 79 & Maruadih Rly. Settl. & - & - & - & - & - & - & - & 43 & 41 & 50 & 79 \\
\hline 80 & Kushinagar & - & - & - & - & - & - & - & - & 85 & 78 & 80 \\
\hline 81 & Mau Aima & 45 & 36 & 45 & 55 & 53 & 59 & 48 & 54 & 81 & 81 & 81 \\
\hline 82 & Gopiganj (MB) & - & - & 61 & 54 & 68 & 62 & 52 & 59 & 79 & 75 & 82 \\
\hline 83 & MongraBadshahpur(MB) & 48 & 43 & 49 & 56 & 51 & 54 & 43 & 48 & 68 & 73 & 83 \\
\hline 84 & Suriyawan & - & - & - & - & - & - & - & & 92 & 92 & 84 \\
\hline 85 & Varanasi (CB) & - & - & - & 59 & 76 & 68 & 53 & 51 & 51 & 74 & 85 \\
\hline 86 & Majhauli Raj & - & - & - & - & - & - & - & - & 74 & 79 & 86 \\
\hline 87 & Bilthra Road & - & - & - & - & - & - & - & - & 62 & 62 & 87 \\
\hline 88 & Salempur & - & - & - & - & - & - & - & - & 99 & 86 & 88 \\
\hline 89 & Handia & - & - & - & - & - & - & - & - & 104 & 83 & 89 \\
\hline 90 & Kheta Sarai & - & - & - & - & - & - & - & - & - & - & 90 \\
\hline 91 & Jhusi Kohna & & & & & & & 55 & 73 & 165 & 175 & 91 \\
\hline 92 & Bhadurganj & 55 & 75 & 59 & 68 & 61 & 61 & - & -- & 83 & 87 & 92 \\
\hline 93 & Ghosia Bazar & - & - & - & - & - & - & - & - & 98 & 82 & 93 \\
\hline 94 & Nawabganj & 41 & 50 & 47 & 48 & 55 & 56 & 49 & 58 & 72 & 77 & 94 \\
\hline 95 & Maghar & - & - & - & - & - & - & - & - & 78 & 84 & 95 \\
\hline 96 & Jarwal & - & - & - & - & - & - & - & - & 100 & 98 & 96 \\
\hline 97 & Sarai Aquil & 73 & & 71 & 67 & 59 & 69 & - & - & 87 & 96 & 97 \\
\hline 98 & Saiyad Raja (N.P.) & - & - & - & - & - & - & - & - & 97 & 94 & 98 \\
\hline 99 & Nichlaul & - & - & - & - & - & - & - & - & 103 & 105 & 99 \\
\hline 100 & Sarai Mir & 62 & 64 & 60 & 75 & 73 & 74 & - & - & 108 & 108 & 100 \\
\hline 101 & Pachperwa & - & - & - & - & - & - & - & - & 89 & 88 & 101 \\
\hline 102 & Bharatganj & 70 & 65 & 65 & 77 & 64 & 64 & & 63 & 93 & 89 & 102 \\
\hline 103 & Pipraich & 66 & 57 & 58 & 79 & 60 & 63 & - & - & 82 & 91 & 103 \\
\hline 104 & Bharwari & - & - & - & - & - & 85 & - & - & 84 & 103 & 104 \\
\hline 105 & Kachhwa & 64 & 58 & 62 & 74 & 63 & 65 & 51 & 60 & 86 & 85 & 105 \\
\hline 106 & Ajhua & - & - & - & - & - & - & - & - & 102 & 97 & 106 \\
\hline 107 & Bhatni Bazar & - & - & - & - & - & - & - & - & 91 & 101 & 107 \\
\hline 108 & Khadda & - & - & - & - & - & - & - & - & - & 113 & 108 \\
\hline 109 & Manjhanpur & 69 & & 86 & - & - & - & - & - & 131 & 141 & 109 \\
\hline 110 & Bansgaon & 53 & 31 & 31 & 39 & 37 & 80 & & & & 80 & 110 \\
\hline 111 & Faizabad (CB) & - & - & & 50 & 84 & 97 & 54 & 62 & 76 & 95 & 111 \\
\hline 112 & Chakia & - & - & 67 & 76 & 77 & 79 & - & 64 & 101 & 109 & 112 \\
\hline 113 & Jhusi & 81 & 62 & 78 & 91 & 80 & 90 & - & - & 153 & 153 & 113 \\
\hline 114 & Kota & - & - & - & - & - & - & - & - & & & 114 \\
\hline 115 & Manikpur & 60 & 38 & 53 & 61 & 58 & 66 & - & - & 96 & 100 & 115 \\
\hline 116 & Ashrafpur Kichhauchha & - & - & - & - & - & - & - & - & & 118 & 116 \\
\hline 117 & Ramkola & - & - & - & - & - & - & - & - & 88 & 99 & 117 \\
\hline 118 & Mehnagar & - & - & - & - & - & - & - & - & 121 & 120 & 118 \\
\hline 119 & Pipri & - & - & - & - & - & - & 29 & 69 & 90 & 93 & 119 \\
\hline 120 & Shankargarh & - & - & - & - & - & - & - & - & 120 & 106 & 120 \\
\hline 121 & Ikauna & - & - & - & - & - & 58 & - & - & 118 & 112 & 121 \\
\hline 122 & Karari & - & - & - & - & - & & - & - & 115 & 127 & 122 \\
\hline 123 & Gosaiganj & 68 & 76 & 81 & 85 & 81 & 77 & - & 67 & 80 & 102 & 123 \\
\hline 124 & Bhatpar Rani & - & - & - & - & - & - & - & - & 117 & 119 & 124 \\
\hline 125 & Kerakat & 65 & 67 & 69 & 80 & 92 & 81 & - & 65 & 105 & 132 & 125 \\
\hline 126 & Kotwa & - & - & - & - & - & - & - & - & 136 & 131 & 126 \\
\hline 127 & Pratapgarh City & 52 & 59 & 63 & 71 & 66 & 67 & - & - & 130 & 125 & 127 \\
\hline 128 & Chopan & - & - & - & - & - & - & - & 75 & 128 & 138 & 128 \\
\hline 129 & Bikapur & - & - & - & - & - & - & - & - & 109 & 110 & 129 \\
\hline 130 & Sirathu & - & - & - & - & - & - & - & - & 138 & 130 & 130 \\
\hline 131 & Koraon & - & - & - & - & - & - & - & - & & 155 & 131 \\
\hline 132 & Nizamabad & - & - & 77 & 93 & 72 & 78 & - & - & 133 & 146 & 132 \\
\hline 133 & Gyanpur & - & - & 89 & 63 & 93 & 88 & - & 71 & 119 & 136 & 133 \\
\hline 134 & Khairabad & - & - & - & - & - & - & - & - & 134 & 137 & 134 \\
\hline 135 & Adari & - & - & - & - & - & - & - & - & 123 & 126 & 135 \\
\hline 136 & Phulwaria & - & - & - & - & - & - & - & - & 140 & 121 & 136 \\
\hline 137 & Katghar Lalganj & - & - & - & - & - & - & - & - & 125 & 128 & 137 \\
\hline 138 & Bilariaganj & - & - & - & - & - & - & - & - & 146 & 139 & 138 \\
\hline 139 & Nai Bazar & - & - & - & - & - & - & - & - & 151 & 150 & 139 \\
\hline 140 & Dostpur & - & - & - & - & - & - & - & - & 116 & 117 & 140 \\
\hline 141 & Barhani Bazar & - & - & - & - & - & - & - & - & 129 & 143 & 141 \\
\hline 142 & Dudhi & - & - & - & - & - & - & - & 72 & 113 & 133 & 142 \\
\hline
\end{tabular}




\begin{tabular}{|c|c|c|c|c|c|c|c|c|c|c|c|c|}
\hline 143 & Kaptanganj & - & - & 64 & 52 & 69 & 76 & - & - & 107 & 123 & 143 \\
\hline 144 & Sirsa & 59 & 61 & 66 & 78 & 74 & 73 & - & - & 110 & 135 & 144 \\
\hline 145 & Shivdaspur & - & - & - & - & - & - & - & - & & 158 & 145 \\
\hline 146 & Pipiganj & - & - & - & - & - & - & - & - & 137 & 145 & 146 \\
\hline 147 & Bhadarsa & 57 & 66 & 56 & 69 & 67 & 75 & - & - & 112 & 156 & 147 \\
\hline 148 & Iitifatganj Bazar & - & - & - & - & - & - & - & - & & 144 & 148 \\
\hline 149 & Atraulia & 76 & 72 & 80 & 87 & 89 & 91 & - & - & 145 & 116 & 149 \\
\hline 150 & Hata & - & - & - & - & - & - & - & - & 124 & 124 & 150 \\
\hline 151 & Ledwa Mahua (CT) & - & - & - & - & - & - & - & - & 122 & 114 & 151 \\
\hline 152 & Mundera Bazar & - & - & - & - & - & - & - & - & 166 & 115 & 152 \\
\hline 153 & Dildarnagar F.Bazar & - & - & - & - & - & - & - & - & 126 & 129 & 153 \\
\hline 154 & Risia Bazar & - & - & - & - & - & - & - & - & & 140 & 154 \\
\hline 155 & Jhangipur & - & - & - & - & - & - & - & - & & & 155 \\
\hline 156 & Ajmatgarh & - & - & - & - & - & - & - & - & 141 & 149 & 156 \\
\hline 157 & Gola Bazar & 54 & 55 & 57 & 65 & 62 & 72 & - & - & 111 & 122 & 157 \\
\hline 158 & Bargaon & - & - & - & - & - & - & - & - & & & 158 \\
\hline 159 & Sadat & 74 & - & - & - & - & - & - & - & 127 & 147 & 159 \\
\hline 160 & Ghughuli & - & - & - & - & - & - & - & - & & 142 & 160 \\
\hline 161 & Jiyanpur & - & - & - & - & - & - & - & - & 149 & 159 & 161 \\
\hline 162 & Jarnshila & - & - & - & - & - & - & - & - & & & 162 \\
\hline 163 & Dohrighat & 63 & 73 & 76 & 82 & 78 & 83 & - & - & 135 & 151 & 163 \\
\hline 164 & Anandnagar & - & - & - & - & - & - & - & - & 142 & 157 & 164 \\
\hline 165 & Kurthi Jafarpur & - & - & - & - & - & - & - & - & - & 134 & 165 \\
\hline 166 & Khariya(C.T.) & - & - & - & - & - & - & - & - & - & - & 166 \\
\hline 167 & Air Force Area (CT) & - & - & - & - & - & - & - & - & - & - & 167 \\
\hline 168 & Rampur Karkhana & 56 & 48 & 51 & 62 & 65 & 71 & - & - & 132 & 154 & 168 \\
\hline 169 & Indian Telep. Industry & - & - & - & - & - & - & - & - & & & 169 \\
\hline 170 & Hariharpur (NP) & - & - & - & - & - & - & - & - & 139 & 148 & 170 \\
\hline 171 & Bijpur & - & - & - & - & - & - & - & - & & & 171 \\
\hline 172 & Khargupur & 67 & 74 & 83 & 89 & 91 & 84 & - & - & 144 & 161 & 172 \\
\hline 173 & Mankapur & - & - & - & - & - & - & - & - & 155 & 163 & 173 \\
\hline 174 & Patti & - & - & - & - & - & - & - & - & 147 & 164 & 174 \\
\hline 175 & Jafarabad (N.P.) & 71 & 69 & 72 & 81 & 79 & 86 & - & - & 148 & 152 & 175 \\
\hline 176 & Churk Ghurma & - & - & - & - & - & - & - & 57 & 106 & 111 & 176 \\
\hline 177 & Haraiya & - & - & - & - & - & - & - & - & & 165 & 177 \\
\hline 178 & Shohratgarh & - & - & - & - & - & - & - & - & 143 & 160 & 178 \\
\hline 179 & Phulpur & 75 & 70 & 74 & 86 & 83 & 89 & - & - & 150 & 162 & 179 \\
\hline 180 & Katra Medniganj & 80 & 77 & 85 & 90 & 85 & 95 & - & - & 158 & 171 & 180 \\
\hline 181 & Dulhipur & - & - & - & - & - & - & - & - & & & 181 \\
\hline 182 & Chail & - & - & - & - & - & - & - & - & 152 & 167 & 182 \\
\hline 183 & Antu & - & - & - & - & - & - & - & - & 154 & 166 & 183 \\
\hline 184 & Kandwa & - & - & - & - & - & - & 56 & 74 & 164 & 178 & 184 \\
\hline 185 & Musafirkhana & - & - & - & - & - & - & - & - & & 169 & 185 \\
\hline 186 & Koreripur & - & - & - & - & - & - & - & - & 156 & 168 & 186 \\
\hline 187 & Maharajganj & 78 & 78 & 87 & 92 & & & - & - & 160 & 173 & 187 \\
\hline 188 & Kadipur & - & - & - & - & - & - & - & - & & 174 & 188 \\
\hline 189 & Ghorawal & 82 & 79 & 88 & 94 & 94 & 96 & - & - & 163 & 179 & 189 \\
\hline 190 & Katra & 77 & 71 & 84 & 84 & 88 & 93 & - & - & 162 & 172 & 190 \\
\hline 191 & Ibrahimpur & - & - & - & - & - & - & - & - & & & 191 \\
\hline 192 & Gangapur & - & - & 79 & 88 & 86 & 94 & - & - & 157 & 170 & 192 \\
\hline 193 & Dhanauha & - & - & - & - & - & - & - & - & & & 193 \\
\hline 194 & Gauri Bazar & - & - & - & - & - & - & - & - & 159 & 176 & 194 \\
\hline 195 & Hafizpur & - & - & - & - & - & - & - & - & - & - & 195 \\
\hline 196 & Korwa & - & - & - & - & - & - & - & - & - & - & 196 \\
\hline 197 & Bharuhana (CT) & - & - & - & - & - & - & - & - & - & - & 197 \\
\hline 198 & Bhulepur & - & - & - & - & - & - & - & - & - & - & 198 \\
\hline 199 & Amila & - & - & - & 60 & 71 & 92 & - & - & 161 & 180 & 199 \\
\hline 200 & Chak Imam Ali (CT) & - & - & - & - & - & - & - & - & - & - & 200 \\
\hline 201 & Bakibad & - & - & - & - & - & - & - & - & - & - & 201 \\
\hline 202 & Kataria & - & - & - & - & - & - & - & - & - & - & 202 \\
\hline
\end{tabular}

Source : Kumari, Kiran (2008): “Urbanization and Regional Development in Eastern Uttar Pradesh" Unpublished Ph.D. Thesis, Chapter 4, p. 106-154. 